\title{
Stafrænt sambýli íslensku og ensku
}

\author{
Sigríður Sigurjónsdóttir og Eiríkur Rögnvaldsson
}

- Abstract Um höfundana About the authors $>$ Heimildir

Markmið öndvegisverkefnisins Greining á málfræðilegum afleiðingum stafræens málsambýlis, sem lýst er í pessari grein, er að kanna stöðu íslensku á tímum mikilla samfélags- og tæknibreytinga, með sérstöku tilliti til hugsanlegra áhrifa ensku, einkum í gegnum stafræna miðla. Í fyrsta lagi er reynt að komast að pví hversu mikið mállegt ílag eða máláreiti málnotendur fá, bæði á íslensku og ensku. Í öðru lagi er viðhorf málnotenda kannað, bæði til íslensku og ensku. Í priðja lagi er orðaforði pátttakenda kannaður, bæði íslenskur og enskur. Í fjórða lagi eru pátttakendur beðnir að leggja mat á ýmis málfræðileg atriði, t.d. beðnir að dæma margvíslegar setningar, og pannig reynt að komast að pví hvort aukin enskunotkun í íslensku málsamfélagi nú til dags valdi breytingum á íslensku eða hraði málbreytingum sem hafnar voru fyrir daga snjalltækjabyltingarinnar.

Pessi atriði eru könnuð með fernu móti: Í fyrsta lagi með ítarlegri vefkönnun sem send var til 5.000 manna lagskipts handahófskennds úrtaks Íslendinga á aldrinum 3-98 ára. Í öðru lagi með frekari könnunum og viðtölum við 400 manna sérvalið úrtak úr fyrrnefnda hópnum. Í priðja lagi verður vefkönnunin opnuð öllum sem vilja og reynt með hjálp samfélagsmiðla að fá allt að 10\% landsmanna til pátttöku. Í fjórða lagi eru svo rýnihópar og viðtöl við kennara.

Vefkönnuninni er lokið og verið er að vinna úr niðurstöðum hennar. Fyrstu niðurstöður benda til pess að verulegur munur sé á aldurshópum hvað varðar alla pá meginpætti sem kannaðir voru — ílag, viðhorf, orðaforða og mat á setningum. Nú er unnið að úrvinnslu gagna pannig að unnt verði að gera ítarlega grein fyrir ýmsum páttum niðurstaðnanna og skoða hugsanlega fylgni milli pátta, t.d. milli ílags, viðhorfa og ýmissa mállegra pátta. Í pessari grein er fjallað um meginmarkmið verkefnisins, rannsóknaraðferðir og niðurstöður úr vefkönnun um skjá- og netnotkun barna, svo og um virka og óvirka enskunotkun peirra.

Efnisorð: Málsambýli, skjánotkun, máltaka, málbreytingar, ílag, viðhorf.

\section{Inngangur}

Á undanförnum áratug hafa orðið meiri breytingar á ytra umhverfi íslensks máls en nokkru sinni áđur í málsögunni (sjá t.d. Eirík Rögnvaldsson, 2016). Flestum pessara breytinga fylgir aukin enskunotkun í íslensku málsamfélagi. Sumar breytinganna eru samfélagslegar, svo sem sprenging í fjölda erlendra ferðamanna, mikil fjölgun erlendra starfsmanna í ýmiss konar pjónustustörfum, og alpjóðavæðingin sem hefur áhrif á viðhorf ungs fólks til tungumálsins. Aðrar eru tæknilegar, einkum tilkoma snjallsíma og spjaldtölva sem sítengja fólk við erlendan menningarheim, efnisveitur eins og YouTube og Netflix par sem fólk hefur ótakmarkaðan aðgang að ópýddu erlendu afpreyingarefni, gagnvirkir tölvuleikir par sem spilarar úti um allan 
heim eru í samskiptum sín á milli á ensku, og síðast en ekki síst raddstýrð tæki eins og Amazon Alexa, Google Assistant og Microsoft Cortana sem eru komin inn á fjölda íslenskra heimila og fólk talar ensku við (sbr. Tinnu Frímann Jökulsdóttur, 2018).

Sameiginlegt með pessum tækninýjungum er að pær höfða ekki síst til barna og unglinga, allt niður í börn á máltökuskeiði, og gætu pví haft mikil áhrif á stöðu og framtíð tungunnar. Við vitum samt mjög lítið um hver pau áhrif gætu verið, og hvort og pá hversu mikið peirra er pegar farið að gæta. Skoðanir á stöðu íslenskunnar eru mjög skiptar — sumir telja að hún hafi aldrei staðið sterkar en nú, en öðrum pykir full ástæða til að hafa áhyggjur af stöðu hennar og framtíð (sjá t.d. Eirík Rögnvaldsson, 2016, bls. 17-18). Allir ættu pó að geta verið sammála um að pað sé mjög mikilvægt að fylgjast með próuninni. Vandaðar og viðamiklar rannsóknir á íslensku nútímamáli og stöðu pess hafa aldrei verið brýnni en nú, svo unnt verði að meta hvort pörf sé á að grípa til einhverra aðgerða — og slíkar aðgerðir, ef til kæmi, verða að byggjast á traustum fræðilegum grunni.

Dessar miklu breytingar voru hvatinn að verkefninu Greining á málfreðilegum afleiðingum stafrens málsambýlis (e. „Modeling the Linguistic Consequences of Digital Language Contact“, http:// molicodilaco.hi.is), sem Rannsóknasjóður Íslands veitti priggja ára öndvegisstyrk árið 2016 en höfundar pessarar greinar eru verkefnisstjórar pess. Með höfundum í verkefnisstjórn eru innlendu pátttakendurnir Anton Karl Ingason, lektor í íslenskri málfræði við HÍ, Ari Páll Kristinsson, rannsóknarprófessor á Stofnun Árna Magnússonar í íslenskum fræðum, Ásgrímur Angantýsson, prófessor á Menntavísindasviði HÍ, Birna Arnbjörnsdóttir, prófessor í ensku við HÍ, og Guðbjörg Andrea Jónsdóttir, forstöðumaður Félagsvísindastofnunar HÍ. Einnig vinna að verkefninu doktorsnemarnir Iris Edda Nowenstein, Porbjörg Porvaldsdóttir og Ásrún Jóhannsdóttir, Einar Freyr Sigurðsson, sem var um tíma nýdoktor innan verkefnisins, auk fjölmargra grunn- og framhaldsnema í íslensku og almennum málvísindum.

Auk pess nýtur verkefnið góðs af pátttöku ýmissa sérfræðinga erlendis frá, en peir eru Charles Yang, prófessor í málvísindum við University of Pennsylvania í Bandaríkjunum, Elín Döll Pórðardóttir, prófessor í talmeinafræði við McGill University í Kanada, Joel Wallenberg, lektor í enskri málsögu við Newcastle University í Bretlandi, Laurel MacKenzie, lektor í málvísindum við New York University í Bandaríkjunum, og Noel P. Ó Murchadha, lektor í kennslu tungumála við Trinity College Dublin á Írlandi.

Í verkefninu er sérstaklega hugað аð hugsanlegum afleiðingum aukinnar enskunotkunar í íslensku samfélagi fyrir yngstu málnotendurna. Við höldum pví m.a. fram að ef íslensk börn á máltökuskeiði heyra of litla íslensku talaða gæti afleiðingin orðið sú að íslenskt ílag (e. input), p.e. máláreitið sem pau verða fyrir, nægi ekki til að byggja upp sterkt íslenskt málkerfi og málkennd. Umfjöllunin er sett í samhengi við rannsóknir á tvítyngi og lífvænleik tungumála.

Í pessari grein er meginmarkmiðum verkefnisins lýst og gerð grein fyrir peim rannsóknaraðferðum sem beitt er. Dá eru tekin fáein dæmi um niðurstöður úr netkönnun meðal 3-12 ára barna hvað varðar skjá- og netnotkun annars vegar og virka (tal) og óvirka (hlustun) enskunotkun hins vegar, auk pess sem dæmi eru tekin um viðhorf barna til ensku. Í lokaorðum er lögð áhersla á að hér er aðeins um fyrstu niðurstöður að ræða og margt forvitnilegt á án efa eftir að koma í ljós við frekari úrvinnslu og gagnasöfnun.

\section{Meginmarkmið verkefnisins}

Meginmarkmið verkefnisins er að rannsaka áhrif stafrænna miðla og snjalltækja, sem gjarnan bjóđa upp á gagnvirk samskipti við notendur á ensku, á orðaforða, málkunnáttu og málnotkun Íslendinga og á stöðu og framtíð íslenskunnar. Snjalltækjabyltingin og alpjóðavæðing síðustu ára hafa haft í för með sér aukna enskunotkun víða um heim en í verkefninu verður íslenska notuð sem dæmi um tungumál sem er undir auknu álagi vegna aukinnar notkunar ensku í tækniheiminum og víðar í kjölfar samfélagsbreytinga undanfarinna ára. Dessar breytingar hafa valdið stórauknu enskuáreiti í umhverfi fólks víða um heim en með pví að rannsaka íslensku, 
tungumál lítils málsamfélags par sem upplýsingaflæði er greitt, er vonast til að hægt verði að afla upplýsinga og niðurstaðna sem hægt verði að yfirfæra á önnur tungumál sem eru í svipaðri stöðu og íslenskan. Við teljum íslenskt málsamfélag henta vel til slíkrar rannsóknar par sem pað er nógu stórt til að niðurstöður verkefnisins verði marktækar, og hægt sé að alhæfa út frá peim, en einnig nógu lítið til að auðvelda rannsóknina sjálfa og leiða í ljós einkenni heils málsamfélags.

Skipta má meginmarkmiðum verkefnisins í lýsandi markmið annars vegar og fræðileg markmið hins vegar. Lýsandi markmið verkefnisins eru að afla upplýsinga um enskt máláreiti og enskunotkun Íslendinga og áhrif enskunnar á málkunnáttu, málnotkun og viðhorf Íslendinga til íslensku og ensku. Í fyrsta lagi er ætlunin að fá yfirlit yfir notkun ensku og íslensku í íslensku málsamfélagi í dag par sem magn og eðli ensks og íslensks ílags er skoðað sérstaklega. Í pví sambandi er aflað upplýsinga um notkun pátttakenda á stafrænum miðlum.

Í öđru lagi er kannað hvort nú pegar séu komin fram máltilbrigði eða málbreytingar sem tengist nánu sambýli íslensku og ensku. Spurningin er sem sagt hvort aukin enskunotkun í samfélaginu hafi pegar haft áhrif á orðaforða, beygingar, setningagerð og framburð íslenskunnar par sem form íslenskunnar breytist fyrir áhrif frá ensku. Sem dæmi má nefna orðalagið Hann gaf ræðu, sem er undir greinilegum áhrifum frá ensku, sbr. He gave a speech, í stað íslenska orðalagsins Hann flutti гæðи еðа Hann hélt ræðu.

Í priðja lagi er skoðað hvort notkunarsvið íslenskunnar hafi skerst par sem málnotendur kjósi frekar að nota ensku en íslensku á ákveðnum sviðum, t.d. í tölvuleikjum, eða séu beinlínis neyddir til pess á sviðum par sem íslenskan er ekki í boði, t.d. í margs kyns talstýrðum samskiptum við tölvur og tæki. Í fjórða lagi er viðhorf Íslendinga til ensku og íslensku kannað en viðhorf til tungumáls skiptir mjög miklu máli fyrir stöðu pess og lífvænleik (UNESCO Ad Hoc Expert Group on Endangered Languages, 2011, bls. 3).

Í lýsandi markmiðum verkefnisins er lögð sérstök áhersla á yngri málnotendur, en hægt er að færa rök fyrir pví að enskt máláreiti í samfélaginu í dag sé meira og nái til yngri barna og fleiri sviða en nokkru sinni fyrr vegna notkunar stafrænna miðla og snjalltækja. Enskunotkun málnotenda er einnig mun gagnvirkari en áður par sem málnotendur nota ensku til að eiga samskipti við tölvur og sín á milli á netinu. Í verkefninu er sérstaklega hugað að pví hvort petta aukna enskuáreiti í samfélaginu hafi jafnmikil áhrif á leikskólabörn og börn í fyrstu bekkjum grunnskóla, sem eru enn á aðalmáltökuskeiði, og á eldri börn, unglinga og fullorðna. Máltökuskeið manna er talið ná fram að kynproska en börn eru móttækilegust fyrir máli fyrstu sex til níu árin (DeKeyser og Larson-Hall, 2005; Lenneberg, 1967; Sigríður Sigurjónsdóttir, 2013). Netnotkun og tölvuleikir, sem fara oftast fram á ensku, eru pví líklegir til að hafa mest áhrif á málkunnáttu og málnotkun yngstu barnanna. Par sem pað eru börnin sem munu skila tungunni áfram til næstu kynslóða er pað áhyggjuefni fyrir íslenskuna og framtíð hennar ef staða hennar veikist hjá pessum aldurshópi (sjá Sigríði Sigurjónsdóttur, 2016).

Ef börn alast upp við tvö tungumál á máltökuskeiði verða pau yfirleitt tvítyngd. Pótt tvítyngi sé jákvætt fyrir einstaklinga og samfélög og hafi yfirleitt enga hættu í för með sér fyrir pjóðtungur getur pað verið neikvætt fyrir lítil málsamfélög með fáa málhafa, eins og pað íslenska. Detta er sérstaklega tekið fram í skýrslu UNESCO (UNESCO Ad Hoc Expert Group on Endangered Languages, 2003) um lífvænleik tungumála. Tvítyngi getur nefnilega við ákveðnar málfélagslegar aðstæður verið fyrsta skrefið í tungumáladauða (Romaine, 2013). Slíkar aðstæður geta skapast pegar viðhorf til málanna tveggja eru mjög ólík, t.d. pegar virðing fyrir pjóðtungunni minnkar vegna pess að hún er ekki nothæf á alpjóðavettvangi eða á peim sviðum samfélagsins sem helst höfða til ungs fólks (sjá Sigríði Sigurjónsdóttur, 2016). Sem dæmi um slíkar málfélagslegar aðstæður má nefna sambýli írsku og ensku á Írlandi par sem írskan hefur lotið í læogra haldi fyrir enskunni (sjá t.d. Ó Murchadha og Migge, 2017). Aukið enskuáreiti í málumhverfi barna á máltökuskeiði getur pví leitt til pess að pjóðin verði tvítyngd eða pað sem verra væri hálftyngd (e. incomplete acquisition), ef börn fá hvorki nægilega mikið máláreiti á íslensku né ensku til að byggja upp sterkt málkerfi og málvitund á öđru hvoru málinu eða báđum (sjá Lillo-Martin og Berk, 2003; Newport, 1991; Pearson og Amaral, 2014). 
Fræðileg markmið verkefnisins eru m.a. að próa breytileikalíkan Yang (2002) um máltöku pannig að pað taki tillit til málfélagslegra pátta og tvítyngis. Í grófum dráttum byggist máltökulíkan hans á pví að málkunnátta málnotenda stjórnist af magni og dreifingu ílags á máltökuskeiði. Pannig hefur hann hannað reiknilíkan sem segir fyrir um hvernig málkunnátta næstu kynslóðar verður út frá málumhverfi barna í dag. Eins og ádur er nefnt er Charles Yang pátttakandi í verkefninu og mun hann taka pátt í að próa máltökulíkan sitt pannig að pað taki tillit til áhrifa stafrænna miðla á málumhverfi barna í dag. Dá er einnig vonast til að verkefnið geti varpað ljósi á pær kenningar sem uppi eru um lengd máltökuskeiðs manna og pá málfræðilegu pætti sem menn geta breytt í máli sínu á lífsleiðinni.

Einnig hefur verkefnið pað markmið að próa nýjan mælikvarða á lífvænleik tungumála sem tekur tillit til samfélags- og tæknibreytinga síðustu ára. Fimm prepa mælikvarði UNESCO (UNESCO Ad Hoc Expert Group on Endangered Languages, 2003) og fleiri mælikvarðar sem notaðir hafa verið til að meta lífvænleik tungumála eru komnir nokkuð til ára sinna og próa parf nýjan mælikvarða sem tekur mið af pví stafræna albjóðlega umhverfi sem málin búa nú við. Degar hafa verið lögð drög að vinnu við pennan kvarða (Drude o.fl., 2018).

Í pessu sambandi verður einnig reynt að leggja mat á merkingu og gildi hugtaksins „stafrænn tungumáladauði“ (e. digital language death, Kornai, 2013) sem hefur nokkuð verið notað í umræðu um stöðu og lífvænleik tungumála upp á síðkastið. Með pví er átt við að tungumál verði undir á netinu og í stafrænum samskiptum. Рað er hins vegar óljóst hvort slíkur stafrænn dauði leiðir óhjákvæmilega til algers dauða tungumáls eða hvort tungumál getur lifað góðu lífi 1 raunheiminum pótt pað verði undir í netheimi. Viðamikil könnun META-NET á stöðu 30 evrópumála árið 2012 (Rehm og Uzkoreit, 2012) benti til pess að 2/3 peirra mála sem könnunin tók til næðu ekki að halda í við öra próun í máltækni og stafrænum samskiptum og ættu par með á hættu að deyja stafrænum dauða (sjá Að minnsta kosti 21 Evrópumál á stafrænan dauða á hættu, 2012). Íslenska var meðal peirra evrópumála sem virtust í hættu samkvæmt pessari könnun og stóð raunar næstverst allra málanna 30 (sbr. Eirík Rögnvaldsson, Kristínu M. Jóhannsdóttur, Sigrúnu Helgadóttur og Steinpór Steingrímsson, 2012). Рað er pví mikilvægt að skoða stöðu hennar í ljósi áđurnefnds hugtaks.

\section{Rannsóknaraðferðir}

Rannsóknaraðferðir pær sem beitt er í verkefninu eru fjölbreyttar. Í fyrsta lagi var viðamikil netkönnun send til 5.000 manna lagskipts handahófskennds úrtaks úr pjóðskrá með aðstoð Félagsvísindastofnunar Háskóla Íslands. Pátttakendum var skipt í 11 aldurshópa, frá priggja ára aldri og upp úr - elsti pátttakandinn var 98 ára. Sérstök áhersla var lögð á að ná til barna og unglinga, og pví voru 1.500 manns af pessum 5.000 undir 13 ára aldri.

Netkönnuninni er ætlað að veita yfirlit yfir lýsandi markmið verkefnisins. Allir pátttakendur 13 ára og eldri svöruðu sömu könnuninni. Í fyrsta lagi var reynt að komast að pví hversu mikið mállegt ílag pátttakendur fengju, bæði á íslensku og ensku, og hversu mikil notkun peirra á stafrænum miðlum væri. Í öðru lagi var viðhorf pátttakenda kannað, bæði til íslensku og ensku. Í priðja lagi var orðaforði pátttakenda kannaður, bæði íslenskur og enskur. Í fjórða lagi voru pátttakendur beðnir að dæma margvíslegar setningar og pannig reynt að komast að pví hvort ensk setningagerð valdi hugsanlega breytingum á íslensku eða hraði breytingum sem pegar eru í gangi.

Fyrir börn undir 13 ára aldri voru samdar fjórar mismunandi kannanir - fyrir 3-5 ára, 6-7 ára, 8-9 ára og 10-12 ára. Í pessum könnunum var í meginatriðum reynt að athuga sömu atriði og í fullorðinskönnuninni, en á annan og einfaldari hátt — peim mun einfaldari sem börnin voru yngri. Gert var ráð fyrir að foreldrar barna í yngstu aldurshópunum svöruðu könnuninni en spyrðu börnin sjálf um ýmis atriði. Hins vegar var gert ráð fyrir að börn í eldri aldurshópunum gætu svarað að nokkru leyti sjálf en mælst til pess að foreldrar aðstoðuðu pau við að svara eftir pví sem á pyrfti að halda. 
Netkönnuninni er nú lokið, en hún hófst í júlí 2017 og var pá send til pátttakenda 13 ára og eldri, og til yngri barna í nóvember sama ár. Svarhlutfall reyndist um 41\% í könnuninni sem lögð var fyrir 13 ára og eldri en um 50\% í barnakönnununum fjórum, sem er nokkru lægra en vonast hafði verið til en e.t.v. eðlilegt í ljósi pess hversu viðamikil og tímafrek könnunin var. Úrvinnsla er hafin en skammt á veg komin. Pó hafa pegar verið skrifaðar prjár meistararitgerðir í íslenskri málfræði og ein í máltækni sem byggjast á niðurstöðum úr fullorðinskönnuninni (Dagbjört Guðmundsdóttir, 2018; Elín Dórsdóttir, 2018; Lilja Björk Stefánsdóttir, 2018; Tinna Frímann Jökulsdóttir, 2018). Fylgjast má með framvindu úrvinnslunnar og annarra pátta verkefnisins á vef pess, http://molicodilaco.hi.is.

Næsti páttur rannsóknarinnar er frekari kannanir og viðtöl við 400 manna sérvalið úrtak úr hópi peirra sem tóku pátt í netkönnuninni. Tekin eru tvö tveggja tíma viðtöl við hvern pátttakanda 10 ára og eldri en prjú klukkutíma viðtöl við pátttakendur á aldrinum 3-9 ára, par sem málnotkun, málkunnátta, ílag og viðhorf hvers og eins eru greind og metin og tilteknir pættir málkunnáttunnar kannaðir með viðtölum og sérstökum prófum. Pessi viðtöl hófust vorið 2018 og eru pau tekin við pátttakendur um allt land. Vonast er til að viðtölunum verði að mestu lokið í ársbyrjun 2019.

Einnig er ætlunin að opna netkönnunina sem lýst var í upphafi kaflans fyrir öllum sem vilja taka pátt í henni um leið og viðtölunum lýkur. Könnuninni verður dreift með hjálp samfélagsmiðla og er markmiðið að fá a.m.k. 30.000 pátttakendur. Auk pess hafa verið tekin sérstök viðtöl við kennara í leik- og grunnskólum, svo og hópviðtöl við rýnihópa.

\section{Dæmi um niðurstöður}

Hér verða tekin nokkur dæmi um niðurstöður úr netkönnuninni meðal barna á aldrinum 3-12 ára. Eins og kemur fram í Töflu 1 byggjast niðurstöður könnunarinnar á 724 börnum samtals: 228 börnum í hópi 3-5 ára, 122 í hópi 6-7 ára, 144 í hópi 8-9 ára, og 230 í hópi 10-12 ára. Athugið að í yngsta og elsta aldurshópnum eru prír árgangar í hvorum, en tveir árgangar í miðhópunum og pað skýrir að verulegu leyti mismun á fjölda pátttakenda í hópunum, en svörun var líka dálítið misjöfn eftir aldurshópum. Eins og sést á Töflu 1 er hlutfall svarenda fyrir hverja breytu í töflunni svipað hlutfalli í pýði, en pað styrkir áreiðanleika niðurstaðna okkar.

Tafla 1. Dátttakendur í netkönnun 3-12 ára.

\begin{tabular}{lcccc}
\hline & Fjöldi svarenda & Hlutfall svarenda & Fjöldi í býði & Hlutfall í býði \\
\hline Kyn & & & & \\
Strákur & 358 & $49,40 \%$ & 23.671 & $51,20 \%$ \\
Stelpa & 366 & $50,60 \%$ & 22.555 & $48,80 \%$ \\
Aldur & & & & \\
3-5 ára & 228 & $31,50 \%$ & 13.440 & $29,10 \%$ \\
6-7 ára & 122 & $16,90 \%$ & 9.488 & $20,50 \%$ \\
8-9 ára & 144 & $19,90 \%$ & 9.750 & $21,10 \%$ \\
10-12 ára & 230 & $31,80 \%$ & 13.548 & $29,30 \%$ \\
Búseta & & & & \\
Höfuðborgarsvæði & 452 & $62,40 \%$ & 29.490 & $63,80 \%$ \\
Landsbyggð & 272 & $37,60 \%$ & 16.736 & $36,20 \%$ \\
\hline
\end{tabular}

Á bak við prósentutölurnar í niðurstöðunum sem verða birtar í pessum kafla liggur sá fjöldi barna í hverjum aldurshópi sem sýndur er í Töflu 1 en fjöldinn er samt eilítið misjafn eftir spurningum pví sum börnin svöruðu ekki öllum spurningunum, en frávikið er aldrei mikið. 
Á næstunni er stefnt að ítarlegri úrvinnslu, greiningu og túlkun gagna úr könnuninni og pá fyrst fer að koma í ljós hvort og pá hvernig pau atriði sem hér er fjallað um — skjá- og netnotkun annars vegar og virk og óvirk enskunotkun hins vegar — hafa áhrif á íslenskt mál og viðhorf til pess, hraða málbreytinga o.s.frv. Degar eru komnar fram vísbendingar úr fullorðinsnetkönnuninni (1.615 manns 13 ára og eldri) um tengsl parna á milli hjá unglingum og ungu fólki, nánar tiltekið í peim premur MA-ritgerðum í íslenskri málfræði sem skrifaðar voru innan öndvegisverkefnisins síðastliðið vor.

Athugun Dagbjartar Guðmundsdóttur (2018) leiðir t.d. í ljós að tölvuleikjanotkun með samskiptum við aðra spilara spáir að hluta til fyrir um virka enskunotkun 13-15 ára unglinga sem tóku pátt í netkönnun okkar. Pá benda niðurstöður hennar til pess að peir unglingar sem tala og skrifa ensku mest (svokölluð virk enskunotkun) séu einnig jákvæðastir gagnvart notkun hennar. Tölfræðileg greining hennar á gögnum netkönnunarinnar leiðir sem sagt í ljós samband á milli mikillar gagnvirkrar tölvuleikjaspilunar og virkrar enskunotkunar 13-15 ára unglinga og á milli jákvæðs viðhorfs til ensku og virkrar enskunotkunar í pessum aldurshópi.

Elín Pórsdóttir (2018) kemst að pví í MA-ritgerð sinni að peir 16-20 ára pátttakendur í netkönnun okkar sem nota mikla ensku (tala, skrifa, hlusta og lesa hana daglega) eru líklegri til að sampykkja nýjungar í notkun framsöguháttar og viðtengingarháttar í íslensku sem ekki samræmast málhefo en pátttakendur á pessum aldri sem fá minna enskt ílag og nota ensku minna. Niðurstöður hennar gætu pví bent til pess að aukin enskunotkun í íslensku málsamfélagi í kjölfar snjalltækjabyltingarinnar geti hraðað útbreiðslu málbreytinga sem pegar eru komnar fram í íslensku og par með breytt formi íslenskunnar.

Að lokum leiðir MA-ritgerð Lilju Bjarkar Stefánsdóttur (2018) í ljós að peir 13-98 ára pátttakendur í könnun okkar sem eru mjög eða frekar sammála pví að pá langi til að búa á Íslandi í framtíðinni, svokallaðir heimdragar í ritgerðinni, hafa jákvæðara viðhorf til íslensku en sá hópur sem er mjög eða frekar ósammála eða tekur ekki afstöðu til pessarar fullyrðingar, svokallaðir heimsborgarar. Heimsborgarar hafa hins vegar jákvæðari afstöðu til ensku bótt ekki sé eins mikill munur á viðhorfum hópanna tveggja til ensku og til íslensku. Niðurstöður Lilju Bjarkar leiða sem sagt í ljós samband á milli hugmynda fólks um framtíðarbúsetu sína (sem tengist sjálfsmynd fólks í menningarlegu og alpjóðlegu samhengi) og viðhorfa peirra bæði til íslensku og ensku. Ekki er ólíklegt að slík tengsl skjá- og netnotkunar við virka og óvirka enskunotkun, sem og við íslenskt mál og viðhorf til pess, birtist einnig hjá börnunum í barnahluta könnunar okkar og séu jafnvel skýrari hjá peim en ungmennum og fullorðnu fólki. Um pað verður pó ekkert fullyrt að svo stöddu.

\section{Skjá- og netnotkun}

Í netkönnun okkar var spurt um aðgengi barna að snjallsímum og/eða spjaldtölvum. Samkvæmt niðurstöðum okkar hafa 80\% barna á aldrinum 3-5 ára aðgang að snjalltæki og 84\% 6-7 ára barna. Í eldri hópunum, 8-9 ára og 10-12 ára, hafa nær öll börn (98-99\%) aðgang að snjalltæki. Athugið að foreldrar barna í yngri aldurshópunum tveimur (3-7 ára) svöruðu peim hluta könnunarinnar sem fjallað er um í pessari grein fyrir hönd barna sinna, 8-9 ára börnin svöruðu með hjálp foreldra sinna en 10-12 ára börnin svöruðu spurningunum sjálf.

Reynt var að kanna hversu umfangsmikil net- og snjalltækjanotkun barna væri, m.a. með premur spurningum sem sýndar eru á Myndum 1, 2 og 3. Athugið að á Mynd 1 nær lóđrétti y-ásinn aðeins upp í 35\% en hann nær upp í 100\% á öllum öðrum myndum í greininni. Mynd 1 sýnir aldur barnanna í hverjum aldurshópi pegar pau fengu fyrst aðgang að snjalltæki. Athugið að pessar niðurstöður eru byggðar á peim börnum sem nota snjalltæki á annað borð, sbr. hlutfallstölurnar sem nefndar voru hér að framan um aðgang barna að snjallsímum og/eða spjaldtölvum í hverjum aldurshópi. 


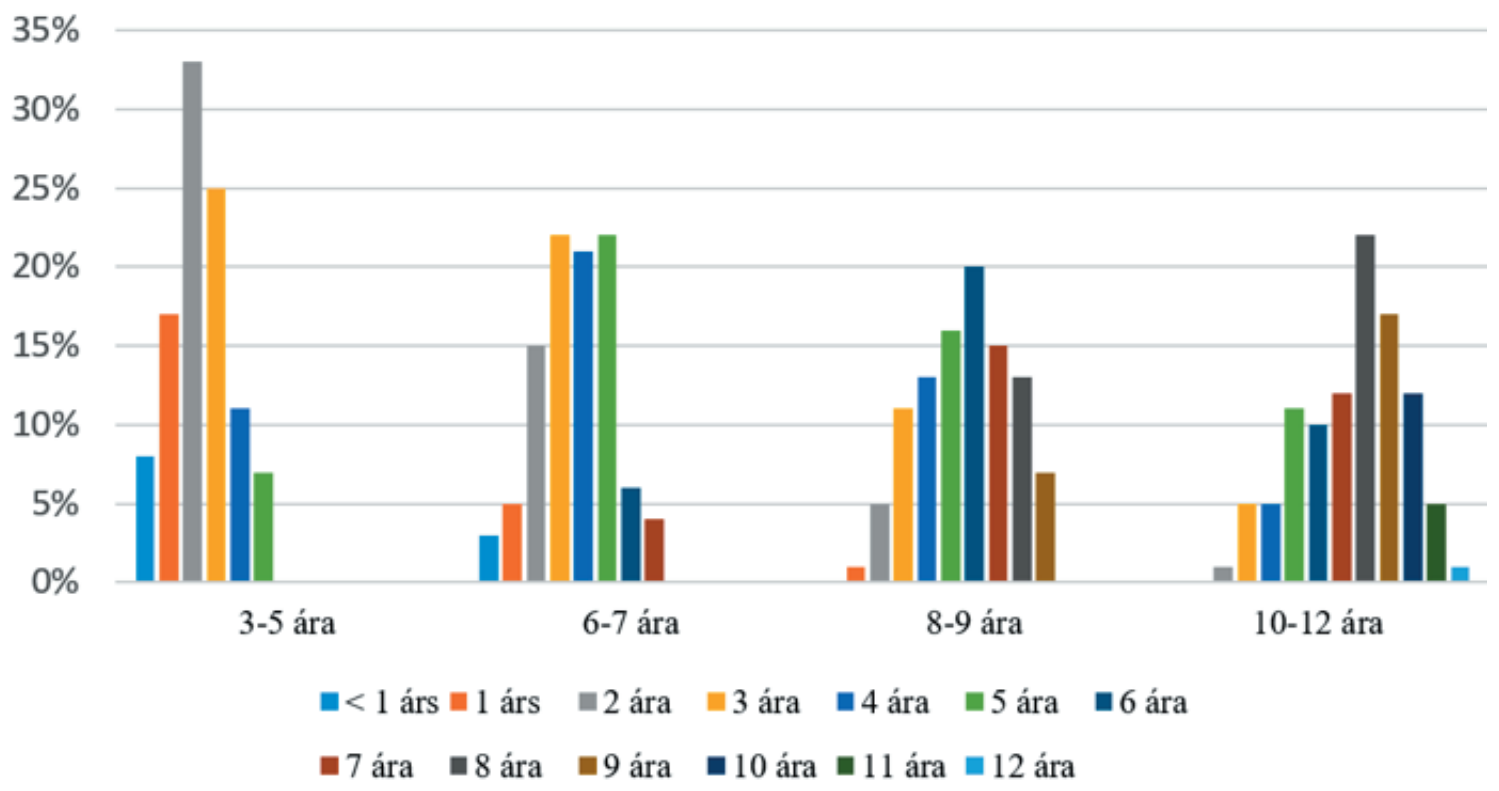

Mynd 1. Hversu gamalt var barnið pegar pað fékk fyrst aðgang að snjalltæki (snjallsíma eða spjaldtölvu)?

Mynd 1 sýnir að börn hefja snjalltækjanotkun sífellt yngri. Í yngsta aldurshópnum sjáum við að 8\% 3-5 ára barnanna byrjuðu að nota snjalltæki fyrir eins árs aldur, 17\% pegar pau voru eins árs og 33\% pegar pau voru tveggja ára. Meira en helmingur, eða 58\%, 3-5 ára barna, sem tók pátt í könnun okkar og notar snjalltæki á annað borð, byrjaði pví að nota pau pegar pau voru tveggja ára eða yngri. Í næstyngsta aldurshópnum voru aðeins 3\% barnanna byrjuð að nota snjalltæki fyrir eins árs aldur, 5\% byrjuðu pegar pau voru eins árs og 15\% pegar pau voru tveggja ára. Hlutfall 6-7 ára barna sem voru tveggja ára eða yngri við upphaf snjalltækjanotkunar er pví 23\% en petta hlutfall er meira en tvöfalt hærra, eða 58\%, í 3-5 ára aldurshópnum.

Í eldri aldurshópunum tveimur, 8-9 ára og 10-12 ára, byrjaði ekkert barn að nota snjalltæki fyrir eins árs aldur og aðeins 1\% 8-9 ára barnanna var eins árs og 5\% tveggja ára pegar snjalltækjanotkun hófst. Hlutfall 8-9 ára barna sem byrjaði að nota snjalltæki tveggja ára eða yngri er pví 6\%. Aðeins 1\% 10-12 ára barna byrjaði slíka notkun tveggja ára, sem er yngsta upphaf snjalltækjanotkunar í peim aldurshópi, en pað er skiljanlegt í ljósi pess að fyrsti snjallsíminn kom á markað árið 2007. Pessar niðurstöður könnunar okkar sýna að íslensk börn eru stöðugt yngri pegar pau hefja snjalltækjanotkun og pessi próun hefur verið mjög hröð á undanförnum árum, par sem upphaf snjalltækjanotkunar færist niður um eitt aldursár á hverjum 2-3 árum, ef marka má svör við pessari spurningu í könnun okkar.

Á Mynd 2 kemur fram að eftir pví sem börnin eldast eyða pau meiri tíma að jafnaði í tölvum og snjalltækjum, eins og við er að búast. 


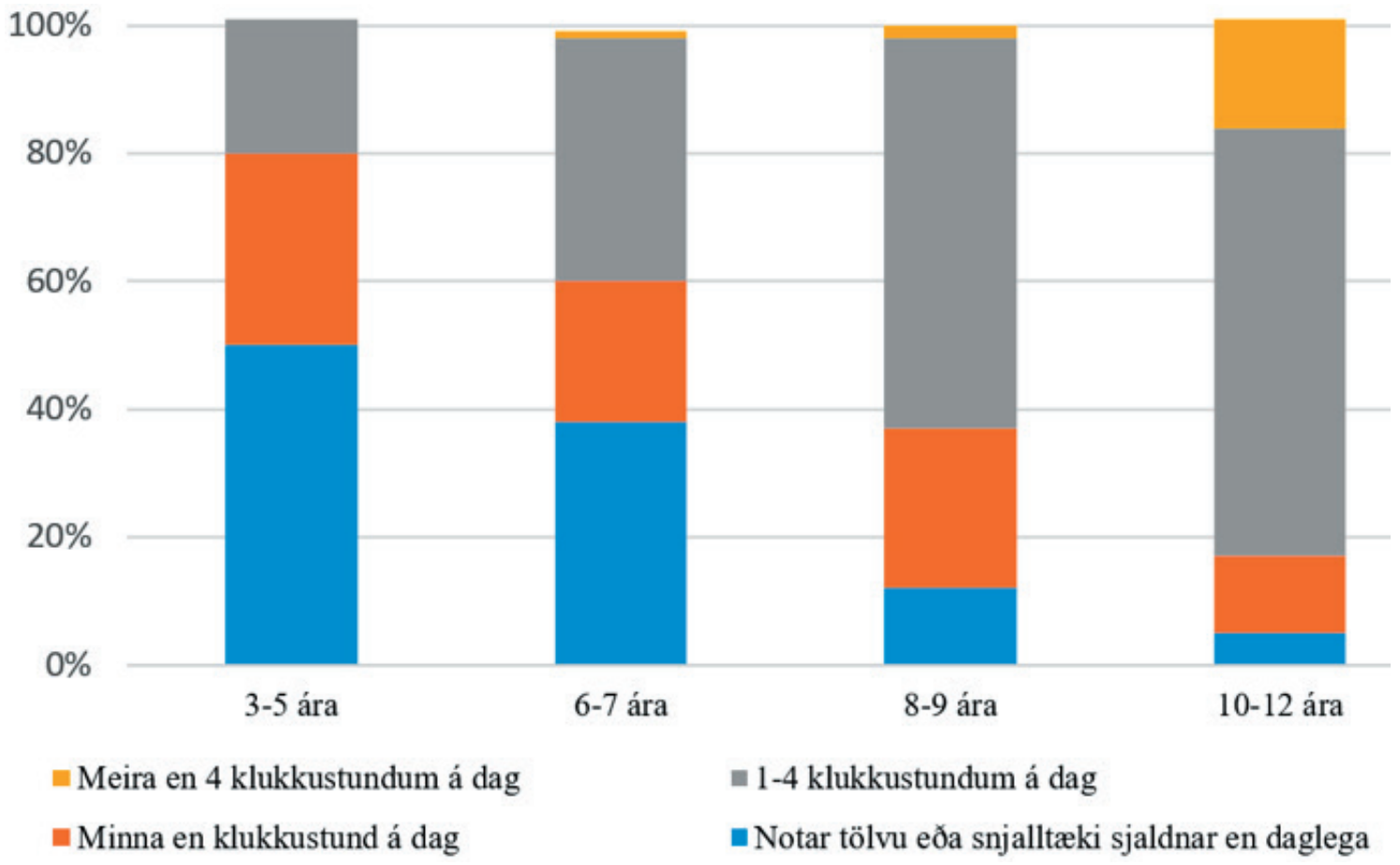

Mynd 2. Hversu miklum tíma eyðir barnið að jafnaði í tölvum og snjalltækjum (snjallsímum og spjaldtölvum)?

Hér er einnig áhugavert að skoða yngsta hópinn, pví pótt meirihluti 3-5 ára barna noti tölvu eða snjalltæki sjaldnar en daglega eða minna en eina klukkustund á dag, pá eyða 19\% 3-5 ára barna 1-4 klukkustundum á dag að jafnaði í tölvum og snjalltækjum. Athugið að pessar niðurstöður eru, eins og á Mynd 1, byggðar á peim börnum sem nota snjalltæki á annað borð, sbr. umfjöllunina í upphafi pessa kafla. Í aldurshópnum 6-7 ára er hlutfall peirra sem eru í tækjunum 1-4 klukkustundir á dag komið upp í 38\%, petta hlutfall er 61\% hjá 8-9 ára börnum og 67\% hjá 10-12 ára börnum. Í elsta aldurshópnum eru svo 17\% barnanna meira en 4 klukkustundir á dag í tölvum og snjalltækjum.

Mynd 3 sýnir að netnotkun íslenskra barna eykst eftir pví sem pau eldast, eins og við er að búast.

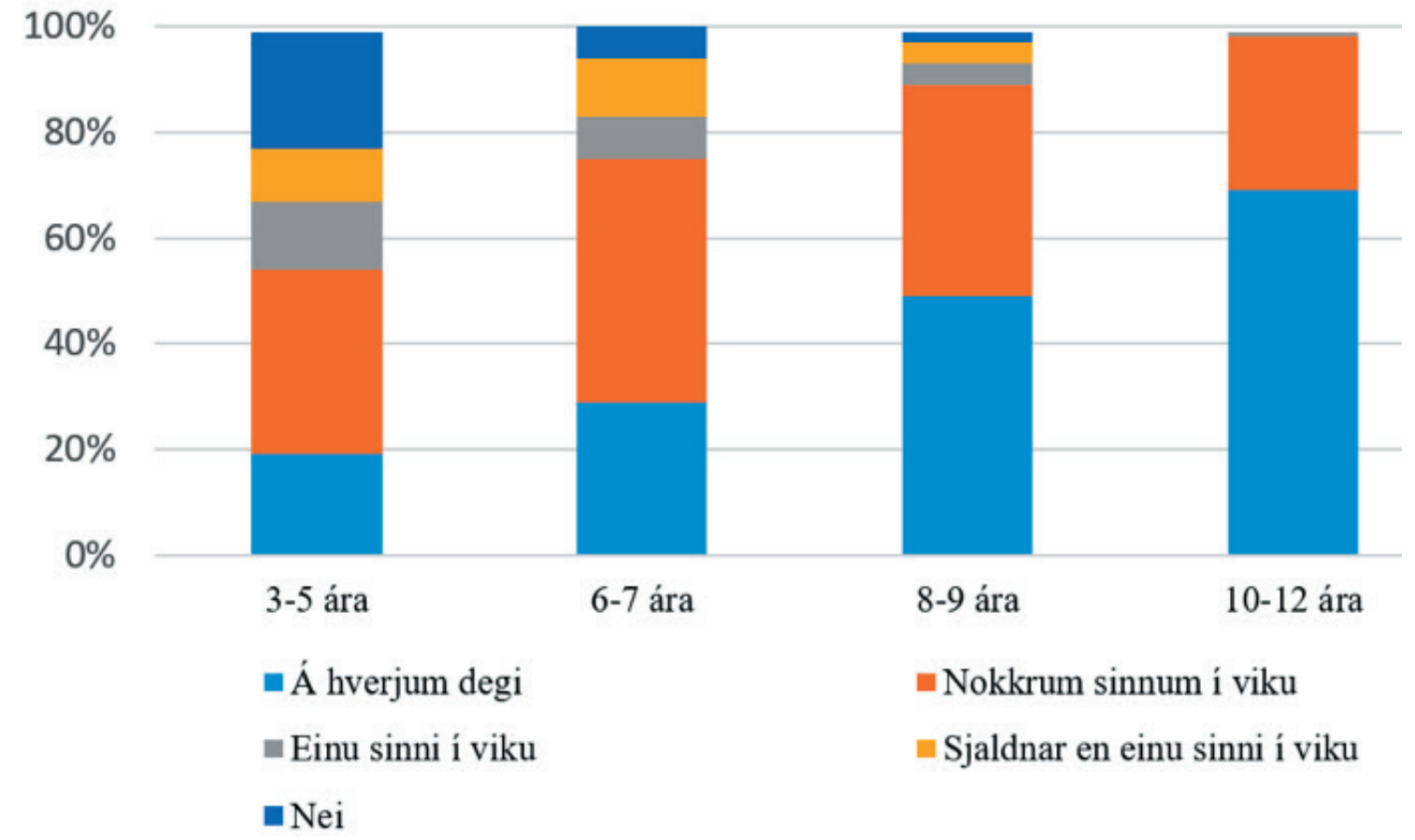

Mynd 3. Notar barnið netið? 
Flest 3-5 ára börnin nota netið ekki eða sjaldnar en á hverjum degi en pað er áhugavert að 19\% peirra virðast samt samkvæmt niðurstöðum rannsóknar okkar nota netið á hverjum degi. Dagleg netnotkun eykst eftir pví sem börnin eldast og er komin í 69\% í elsta aldurshópnum. Í yngsta aldurshópnum nota $54 \%$ netið nokkrum sinnum í viku eða daglega, en nær öll börn í elsta aldurshópnum, eða 98\%, nota netið a.m.k. nokkrum sinnum í viku.

Forvitnilegt er að bera saman svör við peim premur spurningum í könnun okkar sem sýndar eru á Myndum 1, 2 og 3 og niðurstöður könnunar Steingerðar Ólafsdóttur (2017) á snjalltækjanotkun barna. Samanburður milli pessara tveggja rannsókna er pó ekki alveg einfaldur — bæði er aldurshópaskipting Steingerðar önnur (0-1 árs, 2-4 ára, 5-8 ára) og spurningar aðrar. Að breyttu breytanda verður pó ekki annað séð en samræmi sé á milli niðurstaðna rannsóknanna tveggja. Pátttakendur í könnun Steingerðar voru 851 barn á aldrinum 0-8 ára. Hlutfall barna sem notar netið nokkrum sinnum í viku eða oftar er 41\% í aldurshópnum 2-4 ára og 68\% íaldurshópnum 5-8 ára. Í könnun okkar er petta hlutfall 54\% í 3-5 ára aldurshópnum og 75\% i 6-7 ára aldurshópnum. Hlutfall daglegrar netnotkunar í könnun Steingerðar er 13\% í 2-4 ára aldurshópnum og 27\% 1́ 5-8 ára aldurshópnum en í könnun okkar er pað 19\% í 3-5 ára aldurshópnum og 29\% í 6-7 ára aldurshópnum.

Samkvæmt SAFT-könnun á netnotkun barna og unglinga frá árinu 2013 byrjuðu 62\% íslenskra barna að nota netið á aldrinum 5-8 ára, tæp 12\% á aldrinum 3-4 ára og 2\% voru yngri en priggja ára. Niðurstöður SAFT-könnunarinnar sýna einnig að yngri börnin, börn í 4. og 5 . bekk árið 2013, voru yngri pegar pau byrjuðu að nota netið en eldri börnin í könnuninni, börn og unglingar í 6.-10. bekk grunnskóla. Pannig var hlutfall barna sem byrjaði að nota netið fjögurra ára eða yngri 24\%-27\% í 4. og 5. bekk árið 2013 en 6\%-13\% i 6.-10. bekk (sjá Sigríði Sigurjónsdóttur, 2016).

Í SAFT-könnuninni er spurt um netnotkun en í könnun Steingerðar Ólafsdóttur (2017) og könnun okkar er spurt um snjalltækjanotkun. Detta er vissulega ekki sami hluturinn en pó nátengt - hvort tveggja vísar til notkunar á stafrænum miðlum. Samanburður á niðurstöðum SAFT-könnunarinnar (2013, bls. 26-27) annars vegar og á niðurstöðum könnunar Steingerðar Ólafsdóttur (2017) og netkönnunar barnahluta öndvegisverkefnis okkar hins vegar sýnir að frá árinu 2013 hafa orðið miklar breytingar á aldri íslenskra barna pegar pau hefja net- og snjalltækjanotkun. Samkvæmt könnun okkar á 3-12 ára börnum í nóvember 2017- maí2018 byrjuðu $40 \%$ barnanna að nota snjalltæki á aldrinum 5-8 ára, samanborið við 62\% sem byrjuðu að nota netið á pessum aldri samkvæmt SAFT-könnuninni 2013, 26\% á aldrinum 3-4 ára samanborið við 12\% árið 2013 og 20\% voru yngri en priggja ára í könnun okkar samanborið við 2\% árið 2013. Börn í dag byrja pví að nota snjalltæki miklu yngri en börn byrjuðu að nota netið árið 2013 og próunin hefur verið mjög hröð á allra síðustu árum.

\section{Virk og óvirk enskunotkun og viðhorf til ensku}

Meðal pess sem reynt er að fá yfirlit yfir í rannsókninni er enskunotkun barnanna, bæði óvirk (hlustun og lestur) og virk (tal og ritun). Óvirka notkunin var m.a. könnuð með spurningunni á Mynd 4. 


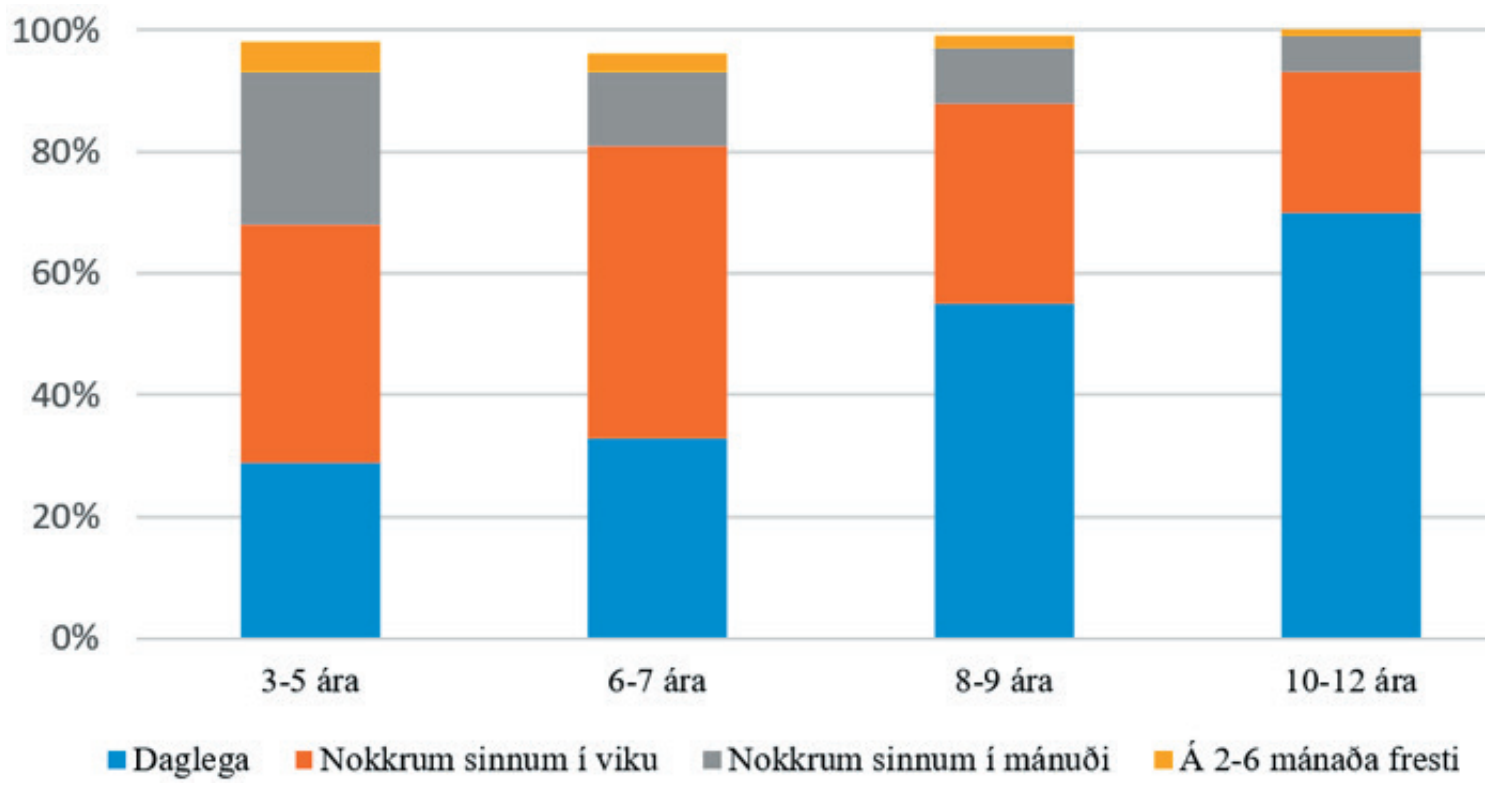

Mynd 4. Áætlaðu gróflega hversu oft að meðaltali barnið hlustar á talaða ensku. Spurningin á við hlustun á allt tal við allar aðstæður. Spurningin tekur líka til hlustunar á sjónvarpsefni, upplestur (ef lesið er fyrir barnið) og hvers kyns barnaefni. Hér er pó ekki átt við tónlist sem flutt er á ensku.

Mynd 4 sýnir að samkvæmt niðurstöðum netkönnunar okkar heyra börn frá unga aldri mikið af talaðri ensku — allt frá 29\% á hverjum degi í yngsta hópnum upp í 70\% í peim elsta. Hlutfall 3-12 ára barna sem hlustar á talaða ensku daglega eða nokkrum sinnum í viku er frá 68\% upp í 93\%. Væntanlega skýrist mikill hluti af pessu enska ílagi sem felst í hlustun á talaða ensku af áhorfi á sjónvarp, YouTube, Netflix, o.p.h.

Virk enskunotkun barnanna var m.a. könnuð með spurningunni á Mynd 5. Athugið að ekki er gerður greinarmunur á pví í spurningunni hvort barnið tjáir sig eða reynir að tjá sig á ensku í stökum orðum, einstökum setningum eða heilu samtölunum. Petta skýrist væntanlega betur í viðtölunum og könnununum sem nú eru í gangi.

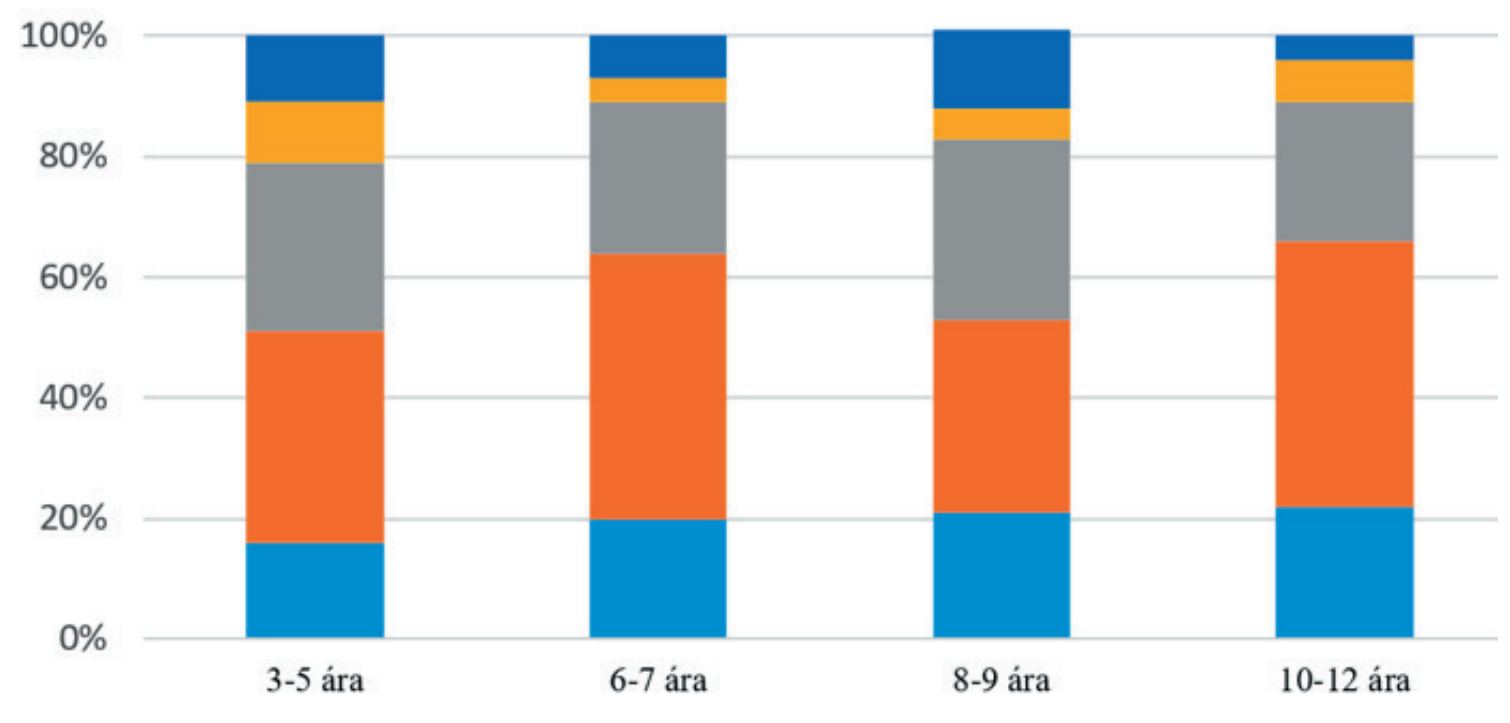

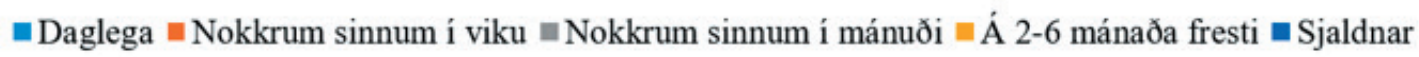

Mynd 5. Áætlaðu gróflega hversu oft að meðaltali barnið talar eða reynir að tala ensku. Hér er átt við alla tjáningu, allt frá stökum orðum yfir í lengri setningar. 
Samkvæmt niðurstöðunum sem sýndar eru á Mynd 5 tala 16\% barna á aldrinum 3-5 ára ensku á hverjum degi, eða bera sig til við pað. Hlutfall barna sem talar eða reynir að tala ensku er ótrúlega svipað í öllum aldurshópunum — 20\% hjá 6-7 ára börnum, 21\% hjá 8-9 ára börnum, og 22\% hjá 10-12 ára börnum. Degar skoðað er hversu hátt hlutfall barna í hverjum aldurshópi talar ensku nokkrum sinnum í viku eða daglega kemur í ljós að pað er rúmur helmingur barna, eða 51\% í yngsta aldurshópnum, 64\% i 6-7 ára aldurshópnum, 53\% í 8-9 ára aldurshópnum og 66\% 1 10-12 ára aldurshópnum. Meira en helmingur barna í öllum aldurshópum, eða frá 51\% upp í 66\%, talar pví eða reynir að tala ensku daglega eða nokkrum sinnum í viku. Rétt er að hafa í huga að inni í pessum tölum eru börn sem alast upp á tvítyngdum heimilum, en pað breytir pví ekki að pessar niðurstöður gefa vísbendingu um umfang talaðrar ensku í málumhverfi íslenskra barna í dag.

Dví er oft haldið fram að töluvert sé orðið um að íslensk börn tali saman á ensku pegar pau eru að leika sér. Við könnuðum petta með pví að fá viðbrögð við fullyrðingunum á Myndum 6 og 7.

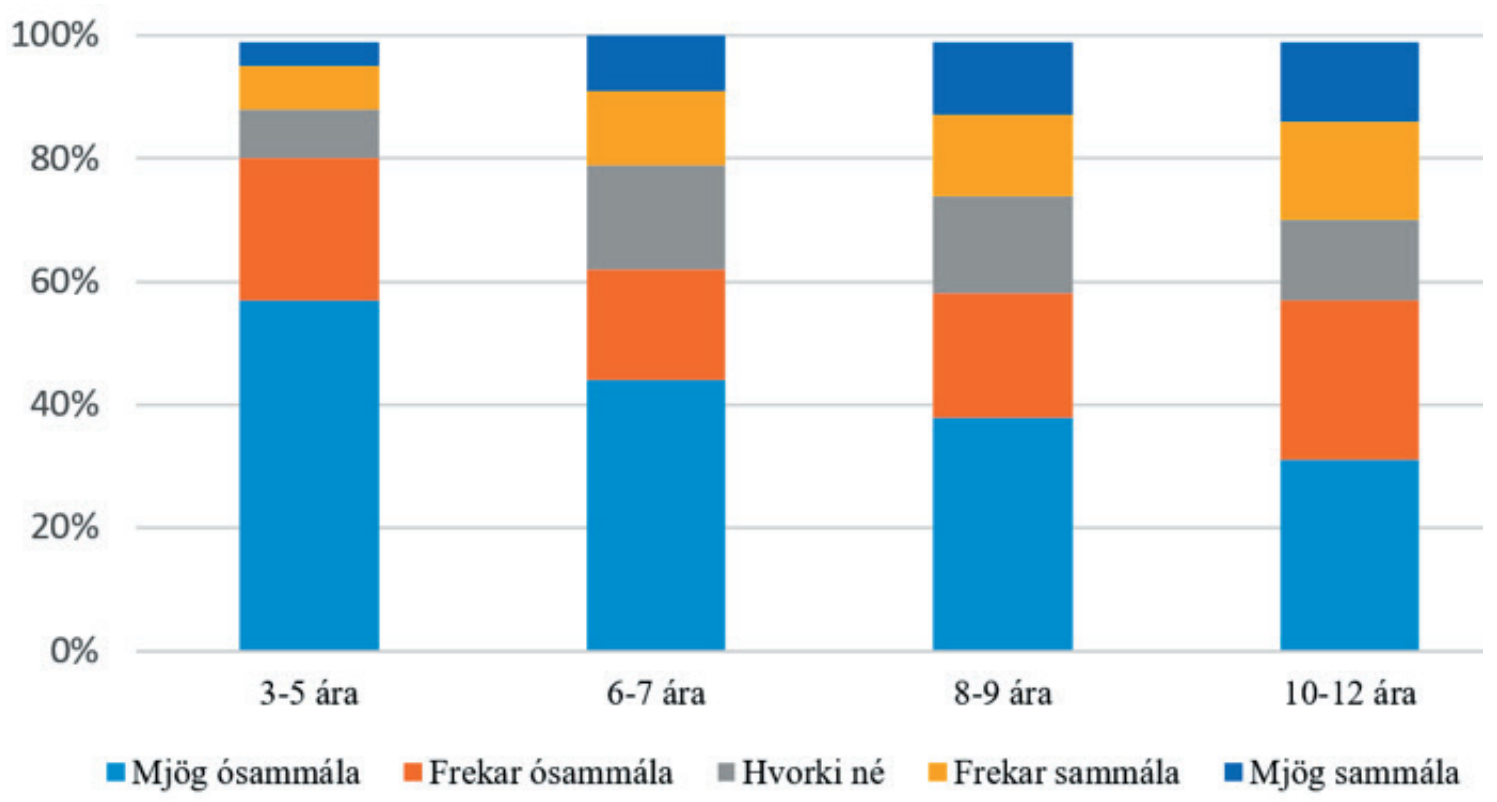

Mynd 6. Barnið leikur sér stundum við vini sína á ensku.

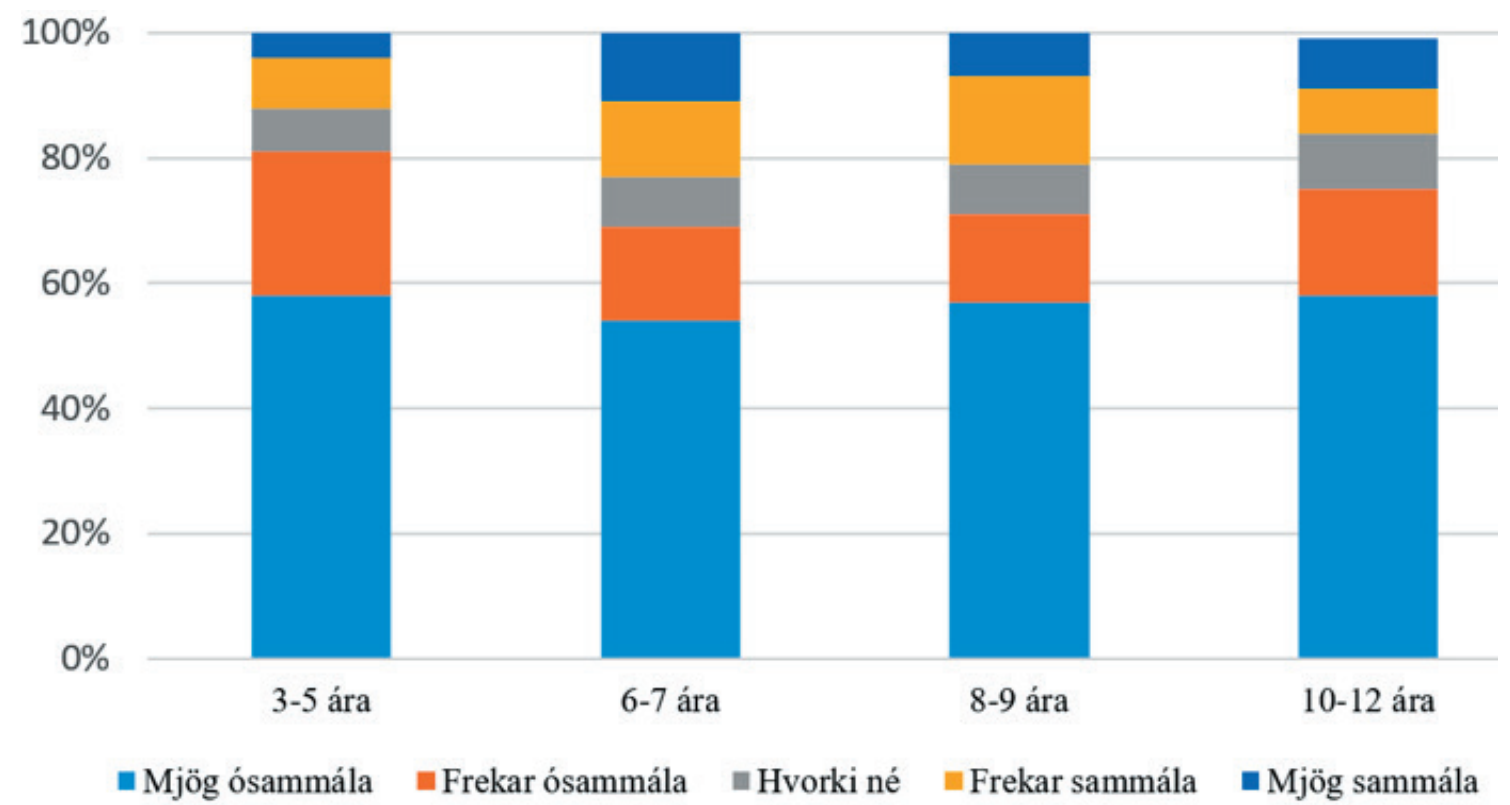

Mynd 7. Barnið leikur sér stundum á ensku pegar pað er eitt. 
Myndir 6 og 7 sýna að nokkuð er um að börn leiki sér á ensku, bæði ein og við önnur börn. Hjá yngri börnunum virðist litlu skipta hvort pau eru ein eða í leik við önnur börn. Foreldrar 11\%-12\% yngstu barnanna eru frekar eða mjög sammála pví að börnin leiki sér stundum á ensku, ein eða við önnur börn, og 21\%-22\% 6-7 ára barnanna. Degar börnin eldast eru aftur á móti meiri líkur á að pau leiki sér á ensku við önnur börn en ef pau eru ein. 15\% 10-12 ára barna eru frekar eða mjög sammála pví að pau leiki sér á ensku ein, en hlutfallið fer upp í 29\% pegar pau eru í leik með öðrum. Dað virðist pví vera einhver fótur fyrir peim orðrómi sem gengið hefur í samfélaginu undanfarið að íslensk börn leiki sér sum hver á ensku við íslenska vini sína. Hér er pó rétt að hafa í huga að 7\%-8\% pessara barna eru tvítyngd eða fleirtyngd og hafa $2 \%$ peirra ensku að móðurmáli auk íslensku.

Dær niðurstöður sem komið hafa fram í pessum kafla um enskunotkun 3-12 ára íslenskra barna í dag benda til pess að enskunotkun peirra sé bæði óvirk (hlustun) og virk (tal) og að börn í yngsta aldurshópnum, 3-5 ára, skeri sig ekki mikið frá eldri börnunum í pví að hlusta og tala á ensku. Birna Arnbjörnsdóttir (2018, bls. 37-39) fjallar um rannsóknir sínar og samstarfsmanna á enskunotkun íslenskra barna á árunum 2005-2011, sem í stuttu máli benda til pess að enskunotkun yngri barna sé aðallega óvirk en eftir pví sem börnin eldast verði enskunotkun peirra virkari. Pótt pær niðurstöður úr netkönnun okkar sem birtar eru á Myndum 4-7 gefi til kynna að óvirk enska sé enn frekar hluti af daglegu lífi íslenskra barna en virk enska (sjá einnig Irisi Eddu Nowenstein, Dagbjörtu Guðmundsdóttur og Sigríði Sigurjónsdóttur, 2018), pá er ýmislegt í gögnum okkar sem bendir til pess að enskunotkun yngri barna sé virkari í dag en hún var pegar Birna og samstarfsmenn hennar gerðu sínar kannanir.

Eins og fram hefur komið framar í pessari grein er viðhorf málnotenda eitt af pví sem hefur mikil áhrif á framtíð og lífvænleik tungumála. Detta á sérstaklega við um tvítyngd samfélög — ef viðhorf málnotenda til annars tungumálsins er mun jákvæðara en viðhorf til hins getur pað síðarnefnda átt undir högg að sækja (sjá t.d. Pearson, 2007). Dótt íslenskt samfélag teljist ekki vera tvítyngt miðað við venjulega mælikvarða og skilgreiningar er ljóst að enskan er orðin mjög áberandi í samfélaginu og viðhorf til hennar farin að skipta máli í pessu sambandi. Leiða má líkum að pví að hvatinn til að tileinka sér ensku hafi aldrei verið meiri á Íslandi en í dag, á tímum alpjóðavæðingar, snjalltækjabyltingar, talstýrðra tækja og fjölgunar fólks með annað móðurmál en íslensku hér á landi. Viðhorf barnanna til ensku voru m.a. könnuð með pví að fá viðbrögð við fullyrðingunni á Mynd 8, par sem spurt er um áhuga barnsins á ensku og pví að viðra enskukunnáttu sína.

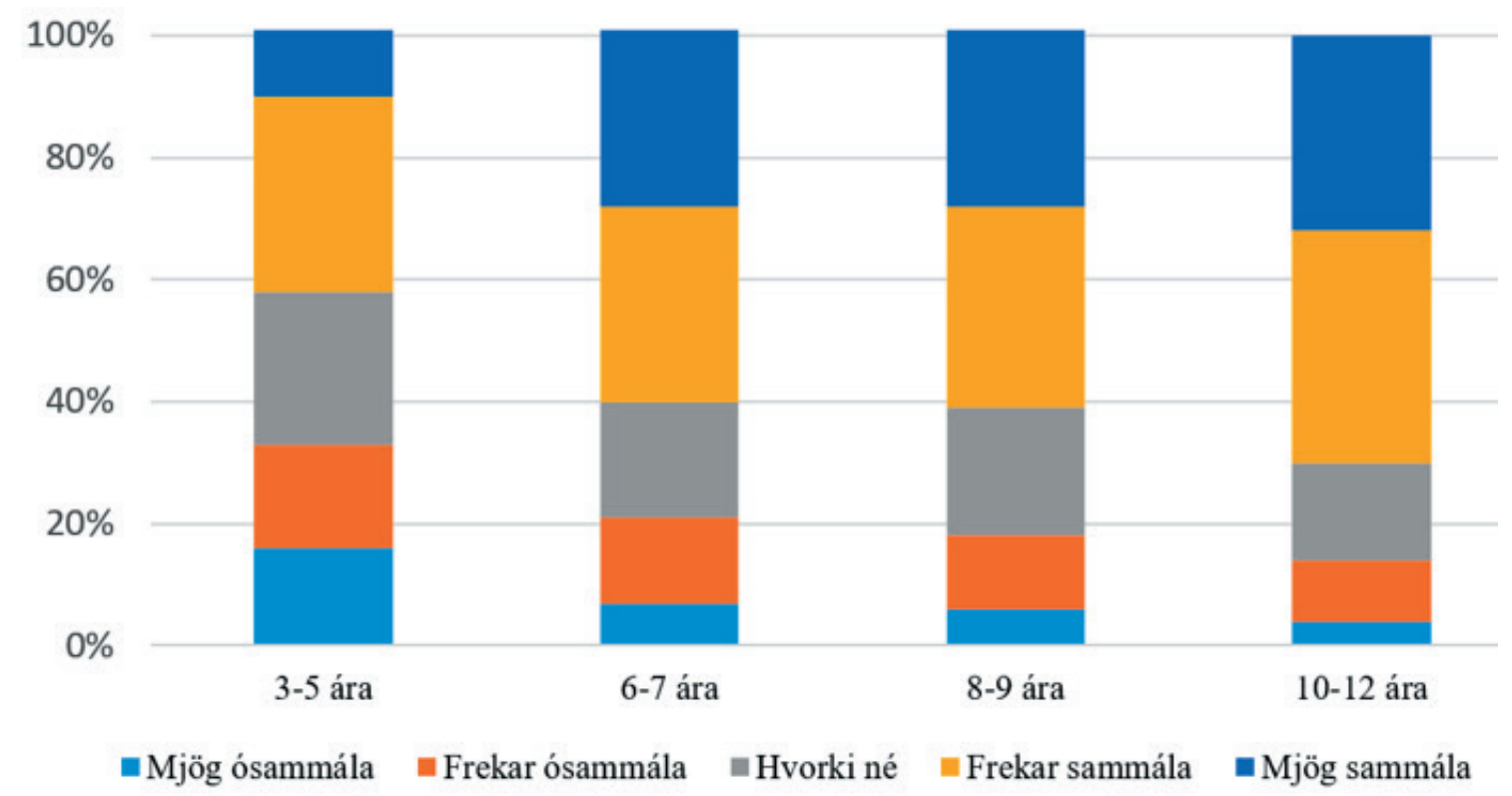

Mynd 8. Barnið hefur áhuga á ensku og sækist eftir að nota enskukunnáttu sína (ef einhver er). 
Mynd 8 sýnir að sá áhugi er greinilega mjög mikill og eykst með aldrinum. Foreldrar 43\% 3-5 ára barna eru frekar eða mjög sammála pessari fullyrðingu og petta hlutfall er komið upp í 70\% hjá 10-12 ára börnum. Dessar niðurstöður benda til pess að enska pyki spennandi og börnin hafi jákvæett viðhorf til hennar.

\section{Lokaorð}

Eins og rakið hefur verið í pessari grein gætu áhrif samfélags- og tæknibreytinga undanfarinna ára á íslenskuna orðið margvísleg. Staða íslenskunnar hefur prengst vegna aukins enskuáreitis í umhverfinu sem getur í fyrsta lagi haft bein áhrif á gerð eða form málsins, t.d. á orðaforða og setningagerð, í öðru lagi skert notkunarsvið íslenskunnar, par sem pað dregur úr virðingu fyrir málinu og áhuga á pví, og í priðja lagi valdið pví að börn fái minna íslenskuáreiti á máltökuskeiði sem getur leitt til pess að pau ná ekki að byggja upp öflugt íslenskt málkerfi.

Fram að pessu hafa petta að mestu verið vangaveltur en nú liggja fyrir fyrstu niðurstöður úr öndvegisverkefninu Greining á málfreðilegum afleiðingum stafrens málsambúlis, sem efnt var til í peim tilgangi að afla upplýsinga um stöðuna. Í pessari grein hefur meginmarkmiðum og rannsóknaraðferðum verkefnisins verið lýst og gerð grein fyrir nokkrum niðurstöðum úr netkönnun meðal 3-12 ára barna, hvað varðar skjá- og netnotkun peirra og virka og óvirka enskunotkun. Dær niðurstöður sýna glögglega að umhverfi og aðstæður íslenskunnar eru að breytast og niðurstöður sem pegar liggja fyrir úr netkönnun meðal 13-98 ára málhafa benda til pess að pær samfélags- og tæknibreytingar sem orðið hafa á undanförnum árum gæu nú pegar verið farnar að hafa áhrif á form íslenskunnar, viðhorf málnotenda til íslensku og ensku og virka enskunotkun ungmenna. Enginn vafi er á pví að áframhaldandi greining og úrvinnsla peirra gagna sem fyrir liggja, og enn er verið að safna, á eftir að leiða margt í ljós um stöðu og framtíðarhorfur íslenskunnar.

\section{Digital Language Contact between Icelandic and English}

The research project Modeling the Linguistic Consequences of Digital Language Contact (Ice. Greining á málfreðilegum afleiðingum stafrans málsambýlis) aims to investigate and model the linguistic consequences of digital language contact, using the rise of English in the Icelandic language community as a test case. This is a three-year project (20162019) financed by a Grant of Excellence from the Icelandic Research Fund awarded to Sigríður Sigurjónsdóttir and Eiríkur Rögnvaldsson, professors at the University of Iceland. A number of other Icelandic and international researchers also participate in the project, in addition to three doctoral students and a number of graduate and undergraduate students. The first half of this paper is a description of the goals and methodology of the project, whereas the second half presents the first results from an online survey of four age groups of 3-12-year-old children, where the focus is on their digital, productive, and receptive English usage.

The main empirical goal of the project is to construct a nationwide profile of the distribution and nature of English and Icelandic input in the Icelandic language community in the digital age and the differences in linguistic knowledge that arise as a result of such novel types of intense encounters with English. The main theoretical goal is to integrate sociological factors and bilingualism into the evolving field of models which derive the linguistic knowledge of speakers from the quantified distribution of input in acquisition, as well as from hypothesized constraints on possible languages. In particular, our work will extend Yang's (2002) Variational Model of Language Acquisition. Furthermore, we aim to develop an index of language vitality designed for measuring effects of digital language contact. 
The implementation of the project includes an online survey sent to a stratified random sample of 5,000 speakers aged 3-98. The purpose is to obtain information on the amount and nature of input the speakers receive in English and Icelandic, as well as on their digital usage. Sociolinguistic variables, such as speakers' language attitudes and self-evaluation of their skills in the respective languages, are also assessed. The data collection for this phase of the project is now complete with a response rate of around $41 \%$ for participants 13 years and older and around 50\% for 3-12-year-old children. We have already begun processing and interpreting the data.

The second step consists of in-depth interviews and further testing sessions with a group comprising 400 speakers selected from among the participants in the online survey according to certain criteria. Each participant 10 years or older is interviewed twice, for two hours each time, whereas 3-9-year-old participants are interviewed three times, for one hour each time. The interviews are being assessed in a careful and precise manner to obtain more fine-grained information on the variables tested in the online survey. These in-depth interviews are now well underway.

The third step of data collection will consist in enlisting the participation of a large proportion of the population (up to 10\%) in an online survey by using crowdsourcing methods focused on social media. This will be a less controlled methodological experiment which, nevertheless, will allow us to test the predictive power of our model. Finally, we are also conducting focus groups and interviews with experienced teachers to collect information on special aspects of language usage among children and adolescents.

The project results presented in this paper derive from the online survey, where the focus is on the digital, productive, and receptive English usage of the 3-12-year-old participants. The children were divided into four age groups: 3-5, 6-7, 8-9, and 1012 years old. Our results show that even in the youngest age group, digital usage (smartphone/tablet and Internet usage) is considerable, and the starting age of such usage seems to be getting lower and lower. In the youngest age group (3-5-year-old children), $58 \%$ of the participants who have access to smartphones or tablets $(80 \%$ of this age group) started using them at the age of two or younger, and $8 \%$ were less than a year old. The results also show that children in all age groups receive a considerable input of spoken English, and their attitudes towards English appear to be very positive. Finally, our results, when compared to earlier studies, indicate that productive English usage among the youngest children is increasing.

Key words: Language contact, screen time, language acquisition, language change, input, attitudes

\section{Um höfundana}

Sigríður Sigurjónsdóttir (siggasig@hi.is) er prófessor í íslenskri málfræði við Íslensku- og menningardeild Háskóla Íslands. Hún lauk doktorsprófi frá University of California í Los Angeles árið 1992 og hefur starfað við Háskóla Íslands frá 1994, sem prófessor frá 2010. Sérsvið hennar er máltaka barna, einkum frá setningafræðilegu sjónarmiði, og málbreytingar og hún hefur birt fjölmargar ritrýndar greinar á pví sviði.

Eiríkur Rögnvaldsson (eirikur@hi.is) er prófessor emeritus í íslenskri málfræði við Íslensku- og menningardeild Háskóla Íslands. Hann lauk cand.mag.-prófi í íslenskri málfræði frá Háskóla Íslands haustið 1982 og var fastur kennari við skólann frá ársbyrjun 1986 til miðs árs 2018 - prófessor frá 1993. Hann hefur fengist við rannsóknir á ýmsum sviðum, einkum samtímalegri og sögulegri setningafræði, svo og gagnamálfræði og máltækni. 


\section{About the authors}

Sigríður Sigurjónsdóttir (siggasig@hi.is) is Professor of Icelandic Language in the Faculty of Icelandic and Comparative Cultural Studies at the University of Iceland. She received her Ph.D. from the University of California at Los Angeles in 1992 and has been employed at the University of Iceland since 1994 - as a full professor since 2010. She specializes mainly in first language acquisition and language change, and has written a number of peer reviewed articles on those subjects.

Eiríkur Rögnvaldsson (eirikur@hi.is) is Professor Emeritus of Icelandic Language in the Faculty of Icelandic and Comparative Cultural Studies at the University of Iceland. He holds a Cand.Mag. degree in Icelandic language from the University of Iceland, where he was employed from 1986 to 2018 - as a full professor since 1993. He has mainly worked on syntax, both synchronic and diachronic, and on corpus linguistics and language technology.

\section{Heimildir}

Að minnsta kosti 21 Evrópumál á stafrænan dauða á hættu. (2012). [Fréttatilkynning um niðurstöður META-NET verkefnisins.] Sótt af http://www.meta-net.eu/whitepapers/press-release-is

Birna Arnbjörnsdóttir. (2018). English exposure, proficiency and use in Iceland. Í Birna Arnbjörnsdóttir og Hafdís Ingvarsdóttir (ritstjórar), Language development across the life span. The impact of English on education and work in Iceland (bls. 35-55). Cham: Springer.

Dagbjört Guðmundsdóttir. (2018). Aldursbundin próun stafrens ílags í málsambýli íslensku og ensku: Kortlagning á umfangi, eðli og áhrifsbreytum (óútgefin MA-ritgerð í íslenskri málfræði). Sótt af https://skemman.is/ handle/1946/29954

DeKeyser, R. og Larson-Hall, J. (2005). What does the critical period really mean? Í J. F. Kroll og A. M. B. De Groot (ritstjórar), Handbook of bilingualism: Psychological approaches (bls. 88-108). Oxford: Oxford University Press.

Drude, S., Anton Karl Ingason, Ari Páll Kristinsson, Birna Arnbjörnsdóttir, Einar Freyr Sigurðsson, Eiríkur Rögnvaldsson, Iris Edda Nowenstein og Sigríður Sigurjónsdóttir. (2018). Digital resources and language use: Expanding the EGIDS scale for language development into the digital domains. Í N. Ostler,V. Ferreira og C. Moseley (ritstjórar), Communities in control: Learning tools and strategies for multilingual endangered language communities. Proceedings of the 21st FEL Conference 19- 21 October 2017 (bls. 98-106). Hungerford: Foundation for Endangered Languages.

Eiríkur Rögnvaldsson. (2016). Um utanaðkomandi aðstæður íslenskrar málpróunar. Skírnir, 190(vor), 17-31.

Eiríkur Rögnvaldsson, Kristín M. Jóhannsdóttir, Sigrún Helgadóttir og Steinpór Steingrímsson. (2012). Íslensk tunga á stafrenni öld / The Icelandic language in the digital age [META-NET White Paper Series]. Berlín: Springer.

Elín Dórsdóttir. (2018). Áhrif aukinnar enskunotkunar á islenska málfreði (óútgefin MA-ritgerð í íslenskri málfræði). Sótt af https://skemman.is/handle/1946/29876

Iris Edda Nowenstein, Dagbjört Guðmundsdóttir og Sigríður Sigurjónsdóttir. (2018). Að tileinka sér móðurmál í tæknivæddum heimi. Skíma, 41,17-21.

Kornai, A. (2013). Digital language death. PLoS ONE, 8(10), e77056. doi:10.1371/journal.pone.0077056

Lenneberg, E. (1967). Biological foundations of language. New York: Wiley.

Lilja Björk Stefánsdóttir. (2018). Heimdragar og heimsborgarar. Menningarlegur hvati í stafrenu málsambýli (óútgefin MA-ritgerð í íslenskri málfræði). Sótt af https://skemman.is/handle/1946/29936

Lillo-Martin, D. og Berk, S. (2003). Acquisition of constituent word order under delayed linguistic exposure. Í B. Beachley, A. Brown og F. Conlin (ritstjórar), Proceedings of the 27th Annual Boston University conference on language development (bls. 484-495). Sommerville, MA: Cascadilla Press.

Newport, E. (1991). Contrasting conceptions of the critical period for language. Í S. Carey og R. Gelman (ritstjórar), The epigenesis of mind (bls. 111-130). New Jersey: Lawrence Erlbaum Associates. 
Ó Murchadha, N. P. og Migge, B. (2017). Support, transmission, education and target varieties in the Celtic languages: An overview. Language, Culture and Curriculum 30(1), 1-12.

Pearson, B. Z. (2007). Social factors in childhood bilingualism in the United States. Applied Psycholinguistics, $28,399-410$.

Pearson, B. Z. og Amaral, L. (2014). Interactions between input factors in bilingual language acquisition: Considerations for minority language maintenance. Í J. Paradis og T. Grüter (ritstjórar), Input and experience in bilingual development (bls. 99-117). Amsterdam: John Benjamins.

Rehm, G. og Uzkoreit, H. (ritstjórar). (2012). META-NET White Paper Series. Berlín: Springer.

Romaine, S. (2013). Environment: Language ecology and language death. Í P. M. Binder og K. Smith (ritstjórar), The language phenomenon: Human communication from milliseconds to millennia (bls. 217-234). Berlín: Springer.

SAFT könnun á netnotkun barna og unglinga. Maí - ágúst 2013 [unnin af Capacent Gallup fyrir Heimili og skóla]. (2013). Sótt af http://saft.is/wpcontent/uploads/2017/09/Barnak\%C3\%B6nnun_4022745_ SAFT_170314.pdf

Sigríður Sigurjónsdóttir. (2013). Máltaka barna og meðfæddur málhæfileiki. Í Höskuldur Dráinsson og Matthew Whelpton (ritstjórar), Chomsky: Mál, sál og samfélag (bls. 107-127). Reykjavík: Háskólaútgáfan.

Sigríður Sigurjónsdóttir. (2016, 18. ágúst). Snjalltækjavæðingin og máltaka íslenskra barna. Hugrás, vefrit Hugvísindasviðs. Sótt af http://hugras.is/2016/08/snjalltaekjavaedingin-og-maltaka-islenskra-barna/

Steingerður Ólafsdóttir. (2017). Smábörnin með snjalltækin.Aðgangur barnanna og viðhorf foreldra. Rádstefnurit Netlu - Menntakvika 2017. Sótt af http://netla.hi.is/serrit/2017/menntakvika_2017/001.pdf

Tinna Frímann Jökulsdóttir. (2018). „I didn’t understand that — please try again“: Samskipti Íslendinga og stafrænna aðstoðarmanna (óútgefin MA-ritgerð í máltækni). Sótt af https://skemman.is/handle/1946/29997

UNESCO Ad Hoc Expert Group on Endangered Languages. (2003). Language vitality and endangerment. Sótt af http://unesdoc.unesco.org/images/0018/001836/ 183699E.pdf

UNESCO Ad Hoc Expert Group on Endangered Languages. (2011). Language vitality and endangerment methodological guideline: Review of application and feedback since 2003. Sótt af http://www.unesco.org/fileadmin/MULTIMEDIA/HQ/CI/CI/pdf/ unesco_language_vitaly_and_endangerment_methodological_guideline.pdf.

Yang, C. (2002). Knowledge and learning in natural language. Oxford: Oxford University Press.

Sigríður Sigurjónsdóttir og Eiríkur Rögnvaldsson. (2018).

Stafrænt sambýli íslensku og ensku

Netla - veftímarit um uppeldi og menntun. Sérrit 2018 - Menntakvika 2018. Menntavísindasvið Háskóla Íslands.

Sótt af http://netla.hi.is/serrit/2018/menntakvika_2018/05.pdf

DOI: https://doi.org/10.24270/serritnetla.2019.29 